

\title{
UPAYA MENINGKATKAN MOTIVASI DAN HASIL BELAJAR SISWA MENGGUNAKAN MODEL COOPERATIVE LEARNING TIPE ROTATING TRIO EXCHANGE (RTE)
}

\author{
Fatkhan Amirul Huda', Adpriyadi², Ika Yulianti ${ }^{3}$ \\ ${ }^{1}$ Program Studi Pendidikan Komputer STKIP Persada Khatulistiwa Sintang \\ ${ }^{2}$ Program Studi Pendidikan Guru PAUD STKIP Persada Khatulistiwa Sintang \\ ${ }^{3}$ Program Studi Pendidikan Guru Sekolah Dasar STKIP Persada Khatulistiwa Sintang \\ email: fatkhanamirulhuda@gmail.com, adpriyadi@gmail.com, kka.ayundha@gmail.co.id
}

\section{Informasi Artikel}

Riwayat Artikel :

Disubmit : 21 April 2020

Direvisi : 7 Mei 2020

Diterima : 10 Mei 2020

Dipublikasi : Juni 2020

\section{Keywords:}

Cooperative Learning

(RTE). Learning

Motivation andLearning

Outcome

\section{Kata Kunci:}

Motivasi belajar,

Hasil belajar

Cooperative Learning (RTE)

\section{ABSTRACT}

The purpose of this research was to improve student's learning motivation and learning outcomes through Rotating Trio Exchange (RTE) Type of Cooperative Learning Model in fourth-grade students of Sekolah Dasar Negeri 14 Mengkurai in academic year 2018/2019. Research form was classroom action research which conducted in two cycles. Data collecting used observation sheets, questionnaire sheets and test questions. Classroom action research results showed that through the Rotating Trio Exchange (RTE. Students learning motivation in the first cycle of overall questions was given, the result was $88.57 \%$. In the second cycle of the overall questions given, the results were $95.71 \%$. While student's cognitive learning outcomes in the first cycle obtained an average value of 69.29 and the second cycle obtained an average value of 91.43 so that an average increase was 22.14. The effective learning results in the first cycle were $71.43 \%$, and the second cycle was $87.86 \%$, while the psychomotor learning outcomes in the first cycle were $87.14 \%$ and the second cycle was $97.14 \%$. The student responses results in the first cycle and the second cycle showed students were very interested and enthusiastic so it can be concluded that there is an improvement in student motivation and learning outcomes through Rotating Trio Exchange (RTE) Type of Cooperative Learning Model.

\section{ABSTRAK}

Tujuan penelitian ini adalah untuk meningkatkan motivasi belajar dan hasil belajar siswa melalui model pembelajaran Cooperative Learning Tipe Rotating Trio Exchange (RTE) pada siswa kelas IV Sekolah Dasar Negeri 14 Mengkurai tahun ajaran 2018/2019. Bentuk penelitian ini adalah penelitian tindakan kelas yang diaksanakan dalam dua siklus. Untuk mengumpulkan data digunakan lembar observasi,lembar angket dan soal tesMotivasi belajar siswa pada siklus I dari keseluruh pertanyaan yang diberikan diperoleh hasil $88,57 \%$. Pada siklus II dari keseluruhan pertanyaan yang diberikandiperoleh hasil sebesar $95,71 \%$. Sedangkan hasil belajar kognitif siswa pada siklus I diperoleh nilai ratarata 69,29 dan pada siklus II diperoleh nilai rata-rata sebesar 91,43 sehingga diperoleh peningkatan rata-rata sebesar 22,14. Hasil belajar afektif pada siklus I di peroleh hasil sebesar 71,43\%, dan siklus II sebesar $87,86 \%$, Sedangkan hasil belajar psikomotorik siklus I sebesar $87,14 \%$ dan siklus II sebesar $97,14 \%$. Hasil respon siswa pada siklus I dan siklus II siswa sangat tertarik dan antusias Sehingga dapat disimpulkan bawah terdapat peningkatan motivasi dan hasil belajar 


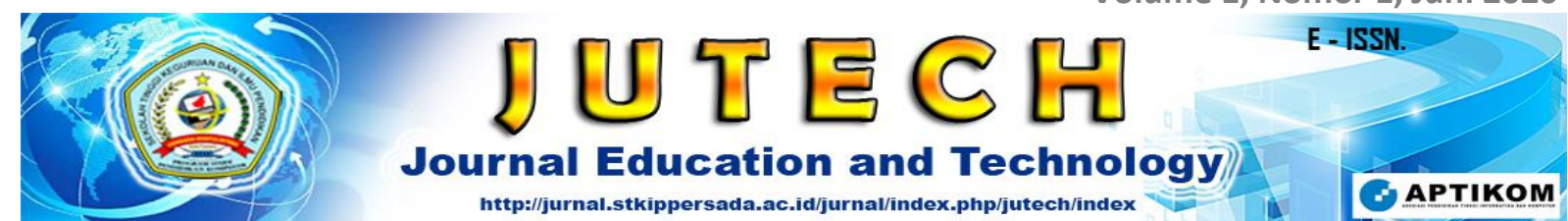

siswa dengan menggunakan model pembelajaran Cooperative Learning Tipe Rotating Trio Exchange (RTE)

\section{PENDAHULUAN}

Berdasarkan pra observasi yang dilakukan pada tanggal 9 April 2018 dan atas izin Kepala Sekolah serta wawancara yang dilakukan bersama guru kelas IV Sekolah Dasar Negeri 14 Mengkurai menyatakan bahwa masih banyak siswa yang kurang termotivasi dalam proses pembelajaran dan mendapat hasil belajar yang kurang baik pada mata pelajaran Ilmu Pengetahuan Alam. Kurangnya motivasi belajar siswa dalam hal ini dapat dilihat dalam proses pembelajaran yang mana siswa kurang termotivasi untuk belajar serta masih kurang aktif dalam belajar, dan peneliti melihat dari hasil nilai ulangan harian yang di tunjukan oleh wali kelas IV SDN 14 Mengkurai.

Hasil belajar siswa yang rendah terlihat dari hasil belajar siswa dengan (KKM) 70 pada mata pelajaran Ilmu Pengetahuan Alam yang masih banyak tidak tuntas. Dari 14 siswa, siswa yang tuntas pada mata pelajaran Ilmu Pengetahuan Alam sebanyak 8 siswa, sedangkan yang tidak tuntas sebanyak 6 siswa. Hal ini disebabkan oleh kurangnya perhatian siswa terhadap guru, dan masih terdapat siswa yang kurang serius dalam belajar sehingga masih banyak siswa yang mendapatkan nilai rendah setiap diberi soal latihan. Sedangkan Hasil belajar afektif yang rendah diakibatkan dengan sikap siswa yang kurang memperhatikan guru dalam menjelaskan materi yang disampaikan. Hal ini terlihat dengan siswa yang sering sibuk sendiri dan mengobrol dikelas ketika guru sedang menjelaskan. Dalam proses pembelajaran khususnya pembelajaran IPA dikelas IV siswa masih belum bisa menghasilkan sebuah karya atau keterampilan yang terdapat dalam materi yang sudah diajarkan sebelumnya serta kurangnya motivasi yang ada pada siswa. Hal ini terlihat dengan tidak adanya kemauan siswa untuk berusaha mencoba sesuatu yang baru. Dengan adanya hal tersebut, maka seorang guru harus dapat membuat variasi pendekatan dalam proses belajar mengajar sehingga dapat membangkitkan motivasi belajar peserta didik dan dapat meningkatkan hasil belajar siswa.

Berdasarkan permasalahan-permasalahan di atas, seharusnya guru dapat menyampaikan materi ajar dengan menggunakan metode ataupun model pembelajaran yang bervariasi sehingga nantinya siswa dapat berpartisipasi aktif didalam proses belajar mengajar dan mendapat nilai yang bagus, dan berdasarkan pra observasi penulis menawarkan bahwa Cooperative Learning Tipe Rotating Trio Exchange (RTE) dapat meningkatkan motivasi dan hasil belajar.

Model Cooperative Learning Tipe Rotating Trio Exchange (RTE) adalah model pembelajaran dimana dalam satukelompok terdiri dari 3 orang siswa, yang diberi nomor 0 , 1, dan 2, nomor 1 berpindah searah jarum jam dan nomor 2 sebaliknya berlawanan arah jarum jam sedangkan nomor 0 tetap di tempat. 
Berdasarkan masalah yang ada pada siswa kelas IV Sekolah Dasar Negeri 14 Mengkurai, perlu penelitian tindakan kelas tentang penggunaan model pembelajaran Cooperative Learning Tipe Rotating Trio Exchange (RTE) pada mata pelajaran Ilmu Pengetahuan Alam. Oleh karena itu, judul penelitian ini adalah "Upaya Meningkatkan Motivasi dan Hasil belajar siswa menggunakan model Cooperative Learning Tipe Rotating Trio Exchange (RTE). pada mata pelajaran ipa materi bagian bagian tumbuhan siswa kelas iv SDN 14 Mengkurai tahun ajaran 2018/2019.

\section{METODE PENELITIAN}

Pendekatan dalam penelitian ini adalah pendekatan kualitatif. Bentuk penelitian yang di gunakan adalah penelitian tindakan kelas.. Suhardjono (2014: 16), dalam prakteknya PTK adalah tindakan yang bermakna melalui prosedur penelitian yang mencakup empat langkah, yaitu (a) perencanaan (planning); (b) tindakan (action); (c) pengamatan (observing); dan (d) refleksi (reflecting).

Sedangkan data dan sumber data yang di gnakan yaitu sumber data primer dan sumber data skunder.

Teknik pengumpulan data dapat digunakan dengan beberapa cara sebagai berikut: Teknik komunikasi langsung, Teknik Komunikasi Tidak Langsung, Teknik Pengukuran, Teknik wawancara teknik dokumentasi, Sedangkan alat pengumpul data yang di gunkan yaitu 1) lembar Observasi, 2) angket , 3) soal tes, 4) dokumentasi.

\section{HASIL DAN PEMBAHASAN}

Berdasarkan pelaksanaan penelitian yang telah dilakukan pada siklus I sampai siklus II, kegiatan guru dalam pelaksanaan pembelajaran dengan menggunakan model pembelajaran Cooperative Learning Tipe Rotating Trio Exchange (RTE) pada mata pelajaran IPA materi bagian bagian tumbuhan mengalami peningkatan yang sangat signifikan dan dapat dikatakan sangat baik hal ini sejalan dengan hasil observasi siklus I ke siklus II yang mengatakn bahwa pada siklus II guru telah melaksanakan semua item yang terdapat dalam observasi guru hal ini dengan di buktikan hasil observasi guru pada siklus I sebesar 92,5\% sedangkan siklus II sebesar 100\%.

Sedangkan untuk aktivitas siswa dalam pelaksanaan pembelajaran dengan menggunakan model pembelajaran Cooperative Learning Tipe Rotating Trio Exchange (RTE) pada mata pelajaran IPA materi bagian bagian tumbuhan mengalami peningkatan yang sangat signifikan pada siklus I dan siklus II ini dapat di lihat dari hasil aktivtas siswa yang telah mengikuti semua aspek penilaian seperti siswa telah melakukan kerja kelompok sesuai dengan prosedur dan siswa memperhatikan guru, adapun hasil dari siklus I sebesar $83,5 \%$ dan siklus III sebesar 
97,5\% dengan rata-rata peningkatan dari siklus

I ke siklus II sebesar $14 \%$.

Berdasarkan pelaksanaan penelitian yang di lakukan dalam pelaksanaan pembelajaran dengan menggunakan model pembelajaran Cooperative Learning Tipe Rotating Trio Exchange (RTE) pada mata pelajaran IPA materi bagian bagian tumbuhan motivasi belajar mengalami peningkatan yang sangat signifikan dan dapat dikatakan sangat baik hal ini dapat di buktikan pada hasil analisis angket di mana pada siklus I mendapatkan rata-rata sebasar $88,7 \%$ pada kategori baik, hal ini menyatakan bahwa siswa telah memiliki gairah untuk belajar, penuh semnagat dalam belajar. Sedangkan pada siklus II mendapatkan ratarata sebasar $95,71 \%$ hal ini menunjukan bahwamotivasi sisiwa mengalami kenaikan dari siklus I ke siklus II sebesar 7,01\% hai ini di buktikan dengan pencapaian indikator memiliki gairah untuk belajar,penuh semnagta,selalu melontarkan pertanyaan sudah sangat baik. Hal ini menunjukan bahwa model pembelajaran Cooperative Learning Tipe Rotating Trio Exchange (RTE) pada mata pelajaran IPA materi bagian bagian tumbuhan dapat meningkatkan motivasi belajar siswa.

Hasil belajar kognitif dengan menggunakan model pembelajaran Cooperative Learning Tipe Rotating Trio Exhange (RTE)pada siswa kelas IV SD 14 mengkurai dapat dikatakan baik dan mengalami peningkatan. Hal ini dapat dilihat berdasarkan ketuntasan belajar siswa mulai dari siklus I sampai siklus II mengalami peningkatan. pada siklus I sebasar 69,29\% dengan ketuntasan klasikal sebesar 71,43\% sedangkan siklus II sebasar 91,43\% dan ketuntasan klasikal sebesar 100\% sedangkan peningkatan dari siklus I ke siklus II sebasar 22,14\% dengan ketuntasan klasikal sebasar $28,57 \%$ hal ini dapat di buktikan dengan hasil kerja siswa pada jenjang $\mathrm{C} 1$ sampai dengan $\mathrm{C} 4$ sudah di laksanakan dengan baik, hal ini menunjukan bahwa model pembelajaran Cooperative Learning Tipe Rotating Trio Exchange (RTE) pada mata pelajaran IPA materi bagian bagian tumbuhan dapat meningkatkan hasil belajar siswa.hasil belajar afektif siswa dengan menggunakan model pembelajaran Cooperative Learning Tipe Rotating Trio Exchange (RTE) mengalami peningkatan dari siklus I sebasar 71,43\% sedangkan pada siklus II sebesar $87,86 \%$ hal ini menujukan bahwa siswa telah melakukan kegiatan yang di terapkan di lingkungan tempat tinggal mereka seperti membuat sapu dari daun kelapa,menggunakan daun pisang sebagai pembungkus kue dan mampu membuang sampah pada tempatnya. Sedangkan hasil belajar psikomorik siswa mengalami peningkatan dari siklus I sebasar $71,43 \%$ dan siklus II sebasar 97,14\% dengan peningkatan dari sikus I ke siklus II sebasar $25.71 \%$, hal ini dapat di buktikan dengan siswa telah terampil dalam menghasilkan produk berupa gambar,siswa telah terampil dalam 


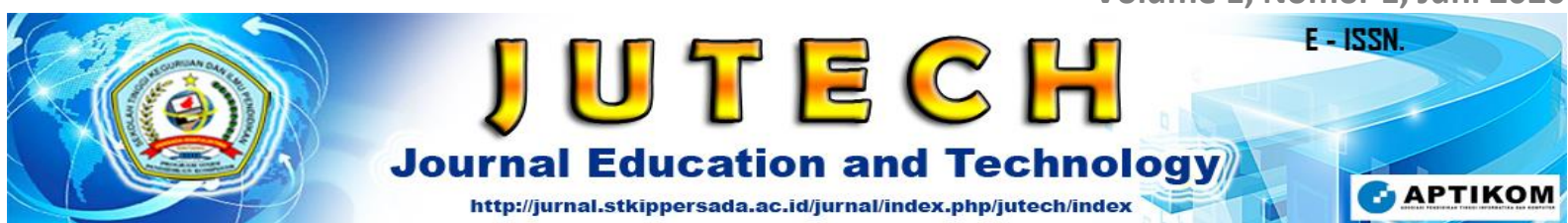

menggambar mewarnai dan menggunting. Dengan hal ini menyatakan bahwa model pembelajaran Cooperative Learning Tipe Rotating Trio Exchange (RTE) dapat meningkatkan hasil belajar siswa.

Berdasarka hasil wawacara kepada siswa di peroleh respon yang sangat positif di mana siswa sangat menyukai dan penuh semangat dala belajar, pembelajaran model model pembelajaran Cooperative Learning Tipe Rotating Trio Exchange (RTE )tidak membuat bosan dan membangkitkan siswa dalam belajar.

\section{SIMPULAN}

Dari proses pembelajaran dengan menggunakan model Cooperarative Learning Tipe Rotating Trio Exchange (RTE) mengalami peningkatan dari siklus I berada pada kreteria sangat baik dan siklus II berada pada kreteria sangat baik.

Sedangkan Peningkatan Motivasi belajar siswa dengan menggunakan model pembelajaranCooperarative Learning Tipe Rotating Trio Exchange (RTE) dari siklus I berada pada kreteria sangat baik mengalami peningkatan pada siklus II berada pada kreteria sangat baik.

Peningkatan hasil belajar kognitif siswa menggunakan model pembelajaran Cooperarative Learning Tipe Rotating Trio Exchange (RTE) dari siklus I berada pada kreteria cukup dan ketuntasan klasikal berada pada kreteria cukup, mengalami peningkatan pada siklus II berada pada kreteria sangat baik dan ketuntasan klasikal berada pada kreteria sangat baik. Sedangkan Hasil belajar afektif siswa dari siklus I berada pada kreteria baik, dan mengalami peningkatan ke siklus II berda pada kreteria sangat baik, dan hasil belajar psikomorik siswa mengalami peningkatan dari siklus I berada pada kreteria sangat baik dan siklus II berada pada kreteria sangat baik. Dan respon siswa menunjukan respon yang sangat baik dan dapat marik perhatian siswa dalam belajar sehingga model Cooperarative Learning Tipe Rotating Trio Exchange (RTE) ini dapat meningkatkan motivasi dan hasil belajar siswa.

\section{DAFTAR RUJUKAN}

Arikunto.,S.,Dkk.,2014. "Penelitian tindakan kelas". Jakarta: PT Bumi Aksaya

Naga M.T. 2013. "penerapan model Cooperative Learning Tipe Rotating Trio Exchange (RTE) untuk meningkatkan aktivitas dan hasil belajar sisswa pada mata pelajatan IPS kelas Va SDN 1 palapa bandar lampung tahun pelajaran 2012/2013" Journal bandar lampung fakultas keguruan dan ilmu pendidikan universitas lampung bandar lampung volume 3 nomor 22013 halaman 13

Sardiman. 2014. "Interaksi dan Motivasi Belajar Mengajar". Jakarata: PT Raja Grafindo Persada

Saroyo, E. 2017. “ Penerapan Model Pembelajaran Insise Outsite Cirle untuk Meningkatkan aktivitas belajar dan hasil belajar kongnitif siswa pada materi keseimbngan ekosistem pada siswa kelas 




VI SDN 35 Sepulau indah" Skripsi.Sintang: Sekolah Tinggi Ilmu Keguruan dan Ilmu Pendidikan Persada Khatulistiwa Sintang
Sugiyono., 2010. "Metode Penelitian Kuantitatif Kualitatif Dan R\&D”. Bandung:Alfa 